$\begin{array}{ll}\text { JISE } 10 \text { (1) } 2021: 95-101 & \text { Journal of Innovative Science Education } \\ \text { UNNES } & \mathrm{http} / / \text { journal.unnes.ac.id/sju/index.php/jise }\end{array}$

\title{
Android-Based E-Booklet Development to Train Students' Critical Thinking And Attitude of Caring for Environment
}

\author{
Pujiasih Pujiasih $^{\bowtie}$, Wiwi Isnaeni, Saiful Ridlo \\ Pascasarjana, Universitas Negeri Semarang, Indonesia
}

\begin{tabular}{|c|c|}
\hline Articl & bstract \\
\hline Published April 2021 & \multirow{3}{*}{$\begin{array}{l}\text { Biology subjects in high school learn everything about life. In this case it } \\
\text { involves skills and reasoning. This study aims to analyze the validity } \\
\text { effectiveness, practicality, and characteristics of android-based e-booklets. This } \\
\text { research is a research and development or R\&D. The development in this study } \\
\text { adopted a } 4 \text {-D model which included four stages namely define, design, } \\
\text { develop, dissemination. The results of the study on the validity test showed that } \\
\text { the material experts obtained a value of } 92.14 \% \text { with a very good category } \\
\text { Based on the results of the validation of media experts obtained a value with a } \\
\text { percentage of } 86.29 \% \text { in the very good category. The results of the research on } \\
\text { the effectiveness of android-based e-booklet are } 1 \text { ) classical completeness } \\
80 \%, 2) \mathrm{N} \text {-Gain test results are different and better (has increased). Cognitive } \\
\text { learning outcomes (students' critical thinking) showed that the percentage of } \\
\text { students' classical completeness was } 88.27 \% \text {, the N-Gain Test was in the high } \\
\text { (53\%), moderate (45\%), low ( } 2 \% \text { ) category. Based on the analysis of affective } \\
\text { and psychomotor competencies with very good criteria. The results of research } \\
\text { on students' attitudes of caring for environment showed that the percentage of } \\
\text { students' scores was } 82 \% \text { with an excellent category. Based on the effectiveness } \\
\text { analysis it can be concluded that the android-based e-booklet is effectively } \\
\text { applied in biodiversity subject. In the analysis of the results of the practicality } \\
\text { of the android-based e-booklet media showed a very good response from } \\
\text { teachers and students. The characteristics of an android-based e-booklet consis } \\
\text { of a cover, a menu display consisting of preface, KI and KD, material, and } \\
\text { evaluation questions. }\end{array}$} \\
\hline $\begin{array}{l}\text { droid- } \\
\text { rning } \\
\text { nent, } \\
\text { r }\end{array}$ & \\
\hline & \\
\hline
\end{tabular}

$\triangle$ correspondence :

Pascasarjana, Universitas Negeri Semarang, Indonesia 


\section{INTRODUCTION}

Biology courses in high school learn everything about life from molecules, cells, tissues, organs, organ systems, organisms or individuals, populations, communities, ecosystems, and biomes. In this case it involves skills and reasoning. To develop reasoning and skills learning that not only can emphasize aspects of understanding and knowledge but also aspects of application, analysis, synthesis, evaluation is needed. For this reason learning that can improve cognitive, affective, and psychomotor learning methods and also that can encourage how to motivate students to be creative, confident, and think critically are needed. In the learning process students' critical thinking skills have an important role in achieving learning achievement, formal reasoning, and creativity because thinking is the core regulator of student actions (Khaeruddin et al., 2019).

The cause of the low quality of students' thinking is due to science education that does not pay attention to the environment around students, so that science learning becomes less meaningful for students. In biodiversity subject students are required to be able to analyze the results of the observation data on various levels of biodiversity (genes, types and ecosystems) in Indonesia. Involving the environment as a source of learning biology is one of the characteristics expected of the curriculum so that learning will be more applicable and meaningful (Ridlo \& Alimah, 2013).

Learning in schools, especially Biology, is still only limited to textbooks and handbooks with few images, not contextually by presenting examples in the surrounding environment. This causes the students' thinking patterns to be limited, and the weakening of students' understanding of biology concepts, so students do not yet have critical thinking skills, as well as a lack of students' caring attitude towards the environment, especially related to plant diversity. This is reinforced by the opinions of several teachers in SMA/MA Negeri in Banjarnegara District, who stated that there were still some problems in the learning process. The teachers do not yet have utilized the potential of the surrounding environment in the learning process. In addition students are allowed to bring a smartphone but it has not been utilized properly.
Riyanto (2015) explains that professional teachers do not only prepare subject matter, but are also required to be creative in using and developing learning media. The availability of learning media will facilitate interaction between teachers and students so that learning activities will be more effective and efficient (Puspita et al., 2017). One of the most popular learning media nowadays is that utilizing an Android application. The use of technology is now more attractive to students than printed teaching materials. Aside from attracting the use of technology in learning it can have a positive influence on students' interest in learning. As pointed out by Hanik et al. (2018) that by applying technology can increase students' interests in participating in learning. Students' understanding of biodiversity subject will be better if it is done by directly observing the level of diversity of living things. Due to limited meeting time, this can be represented by the use of electronic learning media. Learning by using an Android-based e-booklet aims to introduce to students that many different levels of biodiversity are actually easy to learn and understand. The application of an Android - based ebooklet is expected to be able to practice critical thinking skills and foster an attitude of caring for the environment to students.

\section{METHOD}

This research is a research and development (R\&D) (Sugiyono, 2015). Through this research will be developed learning media in the form of an android-based e-booklet on biodiversity subject for grade X SMA / MA. The development in this study adopted a 4-D model developed by Thiagarajan et al., 1984 (Mulyatiningsih, 2014). This model includes four stages namely define, design, develop, dissemination. At the define stage the data obtained in the form of the analysis of the needs of students and teachers. At this stage the instruments used were questionnaires and interview sheets. At the design stage, namely the stage of making media based on the results of identification on the ground At develop stage the data obtained from the results of the validation by using instruments such as questionnaires, testing a large scale using the instrument used in the form of multiple choice questions, and the level of practicality by using the instrument in the form of a questionnaire. At the 
dissemination stage, it is carried out by means of socialization of instructional media through a limited amount of distribution to teachers and students through the android application (playstore). Analysis of research data in the form of the results of the analysis of the validity, effectiveness, practicality, and characteristics of android-based e-booklets.

\section{RESEARCH AND DISCUSSION}

The results of this study present and discuss data obtained from the results of validation by material experts and media experts, the results of the effectiveness test are the results of the application of an android-based e-booklet in learning, the results of practicality tests of an android-based e-booklet that is the response of teachers and students, they also present the results of characteristic analysis of the product developed.

\section{The Validity of the Android-Based E-Booklet Learning Media}

The validity analysis results are obtained from the validity results that have been done by material and media expert lecturers that were aimed at getting information, criticism and suggestions so that the learning media that was developed by researchers become a quality product in accordance with the preparation of a good media. The e-booklet media assessment aspect was adapted from the content feasibility assessment component and the presentation of teaching materials by the National Education Standards Agency (BNSP). Comments and suggestions from material and media experts are used for the process of perfecting the media before testing the use of media by the teacher and students. The results of the validation by material and media experts are presented in Table 1 and 2.

Table 1 . The Results of Material Validation on Android-Based E-Booklet Media on Biodiversity Subject

\begin{tabular}{lll}
\hline Indicator & $\begin{array}{l}\text { Score } \\
\text { obtained }\end{array}$ & $\begin{array}{l}\text { Maximum } \\
\text { score }\end{array}$ \\
\hline Feasibility of contents & 30 & 32 \\
Eligibility of $e$-booklet & 63 & 68 \\
Presentation Feasibility & 36 & 40 \\
\hline Total score & 129 & 140 \\
Percentage (\%) & 92.14 & \\
Criteria & Very good \\
\hline
\end{tabular}

Based on the results of the material validity, it is known that the android-based e-booklet media on biodiversity subject developed has a value of $92.14 \%$ with a very good category. Researchers are permitted to test the use of the media after a good minimum average category is obtained. However, before it is truly tested, the Android - based e-booklet media developed still needs to be improved.

Table 2. The Results of Validity of Android-Based E-Booklet Media on Biodiversity Subject

\begin{tabular}{lll}
\hline Indicator & $\begin{array}{l}\text { Score } \\
\text { obtained }\end{array}$ & $\begin{array}{l}\text { Maximum } \\
\text { score }\end{array}$ \\
\hline Feasibility of contents & 60 & 68 \\
Eligibility of e-booklet & 111 & 132 \\
Presentation Feasibility & 43 & 48 \\
\hline Total score & 214 & 248 \\
Percentage (\%) & 86.29 & \\
Criteria & Very Good \\
\hline
\end{tabular}

Based on the results of the validity of media experts, it can be seen that the android-based ebooklet media on biodiversity subject developed obtained a value with a percentage of $86.29 \%$ which is in the very good category. Researchers are permitted to test the use of media after obtaining a score with a good minimum category. However, before it is truly tested, the android-based e-booklet media for biodiversity subject that is developed still needs to be improved.

\section{Effectiveness of Android-Based E-Booklet \\ Learning Media}

The students' cognitive learning outcomes in learning biodiversity subject by applying an androidbased e-booklet learning media were obtained from the pretest and posttest scores. Pretest scores aim to determine the level of initial ability of students before being given learning activities while the posttest scores are used to determine students' classical completeness criteria. The results of the pretest are presented in Table 3.

The success of learning by implementing an android-based e-booklet media in learning biodiversity subject is proven by cognitive learning outcomes that have reached indicators. The posttest scores already reached grade classical completeness $\geq 80 \%$ by KKM (Minimum Completeness Criteria) of 75 and higher at $88.27 \%$. These results indicate that learning by applying android-based e-booklet media is effectively applied in learning biodiversity subject. 
It it consistent with the results Adi et al. (2016) states that the use of technology-based learning media can improve students' learning outcomes. This was also confirmed by Junaedi et al. (2018) which states that learning by implementing android-based media can improve students' learning outcomes.

Table 3 . Students' Pretest and Posttest Scores by Applying Android-Based E-Booklet Media on Biodiversity Subject

\begin{tabular}{lll}
\hline Information & $\begin{array}{l}\text { Pretest Score } \\
(\mathrm{n}=196)\end{array}$ & $\begin{array}{l}\text { Posttest Score } \\
(\mathrm{n}=196)\end{array}$ \\
\hline Highest score & 60.00 & 100 \\
Lowest score & 28.00 & 56.00 \\
$\begin{array}{l}\text { Average score } \\
\text { Number of students }\end{array}$ & 41.78 & 82.39 \\
$\begin{array}{l}\text { completed } \\
\text { Number of students }\end{array}$ & 196 & 173 \\
$\begin{array}{l}\text { incompleted } \\
\text { Classical completeness } \\
\%\end{array}$ & - & 23 \\
\hline
\end{tabular}

Learning by presenting an android-based ebooklet media and providing LDS (Learning Discussion Sheet) can stimulate students in the classroom to be more interested in participating in the learning process and students can issue constructivism ideas so that new knowledge is developed called cognitive knowledge. In learning process the students are confronted directly with real or contextual examples in LDS, students are immediately confronted with a problem and questions that are factual. This was proven by Sung et al. (2019); Alimah \& Utami (2019) that learning devices that are contextually packaged can be interpreted clearly by students because they are reflected by events in daily life so as to improve student learning outcomes in cognitive, affective, and psychomotoric.

The enhancement of students' learning outcomes in cognitive competencies obtained based on the N-Gain test. The recapitulation results of the N- Gain test are presented in Table 4 .

Table 4. Students' N-Gain Test Results by Implementing Android-Based E-Booklet Media on Biodiversity Subject

\begin{tabular}{llll}
\hline \multirow{2}{*}{$\mathrm{N}$} & \multicolumn{3}{l}{ Percentage of $N$ - Gain Category (\%) } \\
\cline { 2 - 4 } & High & Moderate & Low \\
\hline 196 & 53 & 45 & 2 \\
\hline
\end{tabular}

Table 4 shows the enhancement of students' learning outcomes ( N-Gain ) $53 \%$ is in the high category so that by applying the android-based ebooklet media can be said to be effective in learning biodiversity subject. The high increase in students' learning outcomes after applying the android-based e-booklet media on biodiversity subject in the learning process. The designed media effectively applied as a supplement or learning media in the learning process. Thus, students will more easily apply the concept of the level of biodiversity and provide examples at each level. This is proven by Wiguna et al., (2019) states that there is an increase in students' learning outcomes after applying media based on the learning process.

Significant improvement in learning outcomes can be triggered by several factors, one of which is a pleasant learning atmosphere by using an androidbased e-booklet media that can be opened using a smartphone so that students are very enthusiastic, more interested, active, critical, and motivated in learning activities and discussion. This is in line with the results of research conducted by Arista \& Kuswanto (2018), that media that can be operated using a smartphone can increase enthusiasm, interest, and motivation in learning activities so as to increase the students' independence and concept understanding.

Affective learning outcomes in this study aim to determine students' attitudes during the learning process. The students' attitude to be observed includes six aspects: 1) paying attention, 2) appreciating, 3) cooperation, 4) the ability to ask questions, 5) the ability to think, 6) not feeling always right . A summary of the assessment results of students' attitudes are presented in Table 5 .

Table 5. Results of Students' Affective Assessment by Implementing Android-Based E-Booklet Media on Biodiversity Subject

\begin{tabular}{lll}
\hline Indicator & $\begin{array}{l}\text { Score (\%) } \\
(\mathrm{n}=196)\end{array}$ & Criteria \\
\hline Paying attention & 90.75 & Very good \\
Appreciating & 91.39 & Very good \\
Cooperation & 89.03 & Very good \\
Ability to ask questions & 86.22 & Very good \\
Ability to think & 87.18 & Very good \\
Not feeling always right & 89.60 & Very good \\
\hline
\end{tabular}

The highest of students' affective learning outcomes on the indicator is appreciating and paying 
attention. This is because students are very interested in following the learning process, that is by having media that utilizes students' smartphones. The average of students' affective learning outcomes in the very good category, this is likely from the beginning of the learning process students have already learnt and seek information independently so that when learning activities students pay more attention, appreciate, cooperate, have good ability to ask questions, have the ability to think well, and don't feel always right.

In the learning process students must complete LDS which is equipped with contextual issues through discussion and contribute positively in the formation of attitudes such as appreciating, cooperation, have a good ability to ask questions, having a good opinion ability, and not feeling always right, so that it can encourage students to be critical in solving problems. This is in accordance with the statement of Putri \& Muhta in (2018) which states that in the learning process by applying android media that presents contextual issues through discussion can make a positive contribution in shaping students' attitudes. Based on the results of observational analysis of the students' attitudes, it can be concluded that learning by applying androidbased e-booklet media is effective in learning biodiversity subject, as proved by the increase in students' affective learning outcomes.

Psychomotor learning outcomes in this study are the students' skills in preparing reports or assignments in LDS. Students' assessment of psichomotor aim to learn students' psychomotor when preparing the report or task in LDS. Students' psychomotor observed include five aspects, namely: 1) completeness of the report, 2) clarity of the report, 3) the truth of the concept, 4) accuracy of vocabulary selection, 5) bibliography. The recapitulation of students' psychomotor assessment results are presented in Table 6 .

Psychomotor assessment is done through the student's skill activities in compiling reports or assignments in LDS. Each group is given LDS which is equipped with contextual problems that stimulate students to solve them. Stimulation of these problems will certainly make students motivated to solve them by digging information from various literatures. Thus, students have a great motivation to solve problems and try to solve them so that they have a lot of stock of information. The stock of information will make the students have the readiness and steadiness during presentation so that students can meet the demands of ratings aspects. Explaining the material in sequence and able to answer questions from the teacher and the audience, so that students are able to conclude the results of the discussions well. This is consistent with the opinion of the statement of Rendra et al. (2017); Jalil (2018); Muttaqin et al. (2018) which states that learning by actively involving students can increase students' activity and improve students learning outcomes.

Table 6. Students' Psychomotor Assessment Results by Implementing Android-Based E-Booklet Media on Biodiversity Subject

\begin{tabular}{lll}
\hline Indicator & $\begin{array}{l}\text { Score(\%) } \\
(\mathrm{n}=196)\end{array}$ & Criteria \\
\hline $\begin{array}{l}\text { Completeness of the } \\
\text { report }\end{array}$ & 89.09 & Very good \\
$\begin{array}{l}\text { Clarity of the report } \\
\text { The truth of the }\end{array}$ & 87.76 & $\begin{array}{l}\text { Very good } \\
\text { concept }\end{array}$ \\
$\begin{array}{l}\text { Accuracy of } \\
\text { vocabulary selection }\end{array}$ & 82.78 & Very good \\
Bibliography & 75.00 & Good good \\
\hline
\end{tabular}

The results of learning that students care about the environment in this study are the attitudes students have in loving the environment. In this study to measure students' environmental care attitudes using a scale adapted from NEP S, which is combined with three dimensions of environmental care attitudes namely cognitive, affective, and conitive (Azwar, 2013). Assessment of students' caring attitude towards the environment is done by distributing questionnaires to students, the results of students' caring attitude towards the environment are presented in Table 7.

The results of students' caring attitude towards the environment showed an average of each aspect of $81.8 \%$ with a very good category. This proves that implementing the android-based e-booklet media is able to make a positive contribution in increasing students' affective. Caring attitude towards the environment is an attitude and action which try to prevent damage to the natural environment and its surroundings and to develop efforts to repair the damage to nature (Yaumi, 2014). Loving the environment means preserving the function of the environment which includes structuring policies, utilizing development, maintenance, recovery, 
supervision, and environmental control. The caring attitude towards the environment can be shown by the attitudes and actions that always try to prevent the occurrence of environmental damage and try to repair the damage to nature that has already occurred (Mardikaningtyas, 2016).

Table 7. Assessment Results of Students' Attitude of Caring for Environment After Implementing Android Based E-Booklet Media

\begin{tabular}{|c|c|c|c|c|}
\hline NEPS Aspect & $\Sigma$ Score & Max Score & Score $(\%)$ & Criteria \\
\hline Limits to growth & 650 & 784 & 83 & Very good \\
\hline Anti-antoposentrism (human is not the center of everything) & 641.75 & 784 & 82 & Very good \\
\hline Balance of nature & 627 & 784 & 80 & Good \\
\hline $\begin{array}{l}\text { Anti-exemptionalism (rejection of the idea that human is } \\
\text { free to control nature) }\end{array}$ & 624.5 & 784 & 80 & Good \\
\hline Eco-krisis (ekological disaster) & 656.75 & 784 & 84 & Very good \\
\hline Average & & & 81.8 & \\
\hline
\end{tabular}

\section{Practicality of Android-Based E-Booklet Learning} Media

The results of practicality analysis were obtained from the results of students ' and teachers' assumptions obtained from the questionnaire sheets of students' and teacher' responses given at the end of the lesson. Students' responses showed results of $89.13 \%$ with a very good category. This proves that learning biodiversity subject by applying the androidbased e-booklet media get a good response from students. The application of android-based e-booklet media can increase students' activity in learning, because they not only listen but also find, try, and conclude. Students are more enthusiastic because the learning process is student-centered, whereas the teacher only directs and guides. This was proven by Effendi (2012) that student-centered learning would increase understanding of the material being studied and problem solving while the teacher only directed and guided it as needed.

The results of the analysis of the teacher's response of learning biodiversity subject by applying the android-based e-booklet media by $90.09 \%$ with very good category. The teacher's response to the impression of an android-based e-booklet media is very good, because it can help increase students' activities in participating in learning process so that it helps students understand various kinds of plant diversity and classify them based on the level of biodiversity. Android-based e-booklet media is created to help students in developing the concept of biodiversity subject. The teacher's response to students' activities in learning is very good because it is clear that the students are enthusiastic when discussing . The teacher conveys that the androidbased e-booklet media is an interesting media, up-to- date, easy to use, easy to carry, and the material presented is very clear.

\section{Characteristics of Android-Based E-Booklet Learning Media}

At the stage of making media is by assembling all components such as materials, evaluation, pictures, music, into an android-based e-booklet product. The characteristics of the Android - based ebooklet learning media consist of a cover, a menu display consisting of preface, KI (Core Competencies) and KD (Basic Competencies), material (sub menus: gene diversity, species diversity and ecosystem diversity), and evaluation questions. Following are the characteristics of an Android based e-booklet. The following is a display of the learning media design that has been developed.

\section{CONCLUSION}

Based on the results of research and discussion, it can be concluded that the results of the validity of an android-based e-booklet from material and media experts show very good results so that the media is said to be valid, effective, and practically used on biodiversity subject. The characteristics of an android-based e-booklet include a cover, a menu display consisting of preface, $\mathrm{KI}$ and $\mathrm{KD}$, material (sub menus: gene diversity, species diversity and ecosystem diversity), and evaluation questions.

Based on the results of research and discussion, the suggestions submitted is there are limitations of research in identifying plants, it means not all the plantae kingdom can be identified and presented in the media. Learning by implementing android-based e-booklet needs to be considered and 
applied to other subject as an effort to optimize students' learning outcomes.

\section{REFERENCES}

Adi, NP., Yulianto, RA., Irwan, M., \& Endris, WM. 2016. Android for the 21st Century Learning Media and Its Impact on Students. In Nurtuting Innovative and Higly Literate Generation through Science Education. Proceedings of the 2nd International Seminar on Science Education (ISSE), 173-178.

Alimah, S., \& Utami, L. 2019. Human Reproduction Contextual Case-Based Worksheet to Improve Students' Interpersonal Communication and Collaboration Skills. Biosaintifika: Journal of Biology \& Biology Education, 11(2), 256-263.

Arista, FS., \& Kuswanto, H. 2018. Virtual Physics Laboratory Application Based on the Android Smartphone to Improve Learning Independence and Conceptual Understanding. International Journal of Instruction, 11(1), 1-16.

Azwar S. 2013. Sikap Manusia: Teori dan Pengukurannya. Yogyakarta: Pustaka Pelajar.

Effendi LA. 2012.Pembelajaran Matematika dengan Metode Penemuan Terbimbing untuk Meningkatkan Kemampuan Representasi dan Pemecahan Masalah Matematis Siswa SMA. Jurnal Penelitian Pendidikan 3(2), 1-10.

Hanik, N.R., Hartono S., \& Nugroho AA. 2018. Penerapan Pendekatan Contextual Teaching and Learning Dengan Metode Observasi Untuk Meningkatkan Hasil Belajar Pada Matakuliah Ekologi Dasar. Jurnal Pendidikan Matematika dan IPA, 9(2), 127-138.

Jalil, M. 2018. Peningkatan Aktivitas Dan Hasil Belajar Siswa Materi Tsunami Melalui Metode Diskusi Inkuiri Disertai Penerapan Media Powerpoint Pada Siswa Kelas X SMK Roudlotus Saidiyyah. Genetika, 1(1).

Jamalong, A. 2012. Meningkatkan Hasil Belajar Siswa melalui KooperatifNHT di Kelas X SMA Negeri 1 Bedua Kabupaten Sanggau. Jurnal Pendidikan dan Kebudayaan 4(18), 394-411.

Junaedi, J., Irviani, R., Muslihudin, M., Hidayat, S., Maseleno, A., Gumanti, M., \& Fauzi, A. N. 2018. Application program learning based on Android for students experiences.International Journal of Engineering and Technology (UAE), 7(2.27), 194-198.

Khaeruddin, K., Amin, BD., \& Jasruddin, J. 2019). Analisis keterampilan berpikir kritis pada Kompetensi Dasar Kurikulum 2013 Mata Pelajaran Fisika SMA Analisis keterampilan berpikir kritis pada Kompetensi Dasar Kurikulum
2013 Mata Pelajaran Fisika SMA. Prosiding Seminar Nasional Lembaga Penelitian UNM, 178-181. Mardikaningtyas, AD. 2016. Pengembangan Pembelajaran Pencemaran Lingkungan berbasis Penelitian Fitoremediasi untuk Menunjang Keterampilan Ilmiah, Sikap Peduli Lingkungan, dan Motivasi pada Matakuliah Dasar-dasar Ilmu Lingkungan. Jurnal Pendidikan: Teori, Penelitian, dan Pengembangan, 1(3), 499-506.

Mulyatiningsih, E. 2014. Metode Penelitian Terapan Bidang Pendidikan. Bandung: ALFABETA.

Muttaqin, NH., Yamtinah, S., \& Utomo, SB. 2018. Penerapan Model Pembelajaran Langsung (Direct Instruction) Disertai Diskusi Dan Media Hyperchem Untuk Meningkatkan Aktivitas Dan Prestasi Belajar Pada Materi Ikatan Kimia Kelas X 1 Sma Islam 1 Surakarta Tahun Pelajaran 2016/2017. Jurnal Pendidikan Kimia, 7(1), 62-68.

Puspita, A., Kurniawan AD., \& Rahayu HM. 2017. Pengembangan Media Pembelajaran Booklet Pada Materi Sistem Imun Terhadap Hasil Belajar Siswakelas XI SMA N 8 Pontianak. Jurnal Bioeducation, 4(1), 64-73.

Putri, DPE., \& Muhtadi, A. 2018. Pengembangan multimedia pembelajaran interaktif kimia berbasis android menggunakan prinsip mayer pada materi laju reaksi. Jurnal Inovasi Teknologi Pendidikan, 5(1), 38-47.

Renda, NT., Garminah, NN., \& Dewi, DK. 2017. Implementasi Metode Diskusi Kelompok Untuk Meningkatkan Aktivitas Dan Hasil Belajar Pendidikan Kewarganegaraan. International Journal of Elementary Education, 1(1), 36-46.

Ridlo, S. \& Alimah, S. 2013. Strategi Pembelajaran Biologi Berbasis Kompetensi dan Konservasi. Biosaintifika: Journal of Biology \& Biology Edocation, 5(2), 122-129.

Riyanto, N. 2015. Pemanfaatan Media Light Flash Card Untuk Meningkatkan Aktivitas dan Hasil Belajar IPA Pada Siswa SMP Negeri 2 Bojongsari. EduSains, 3(2), 1-9.

Sugiyono. 2015. Metode Penelitian Pendidikan. Bandung: Alfabeta.

Sung, HY., Hwang, GJ., Chen, CY., \& Liu, WX. 2019. A contextual learning model for developing interactive e-books to improve students' performances of learning the Analects of Confucius. Interactive Learning Environments, 1-14.

Wiguna, D., Irwansyah, FS., Windayani, N., Aulawi, H., \& Ramdhani, MA. (2019, February). Development of android-based chemistry learning media oriented towards generic science skills. Journal of Physics: Conference Series, 1157(4), 042-047.

Yaumi, M. 2014. Pendidikan Karakter: Landasan, Pilar, dan Implementasi. Jakarta: Kencana. 